Volume 6 Issue 2, September 2021:pp. 213 - 223 Copyright @ LamLaj. Faculty of Law, Lambung Mangkurat University, Banjarmasin, South Kalimantan, Indonesia. ISSN: 2502-3136 | e-ISSN: 2502-3128. Open Access at: http://lamlaj.ulm.ac.id/web/

\title{
THE PROTECTION OF ADAPTATION RIGHTS TO E-NOVELS INFRINGED BY THE WEBSITE IN PERSPECTIVE OF COPYRIGHT LAW
}

\author{
Inge Dwisvimiar ${ }^{1}$, Andhima Abdul Ghanny ${ }^{2}$ \\ ${ }^{1}$ Faculty of Law, University of Sultan Ageng Tirtayasa \\ Jl. Raya Palka Km. 3 Sindangsari, Pabuaran, Kab. Serang Provinsi Banten, \\ Indonesia42124E-mail: inge.ahza@gmail.com \\ ${ }^{2}$ Faculty of Law, University of Sultan Ageng Tirtayasa \\ Jl. Raya Palka Km. 3 Sindangsari, Pabuaran, Kab. Serang Provinsi Banten, \\ Indonesia 42124 Email: andhimaghaaniy@gmail.com
}

Submitted : 23/07/2021 Reviewed: 08/08/2021 Accepted:12/09/2021

\begin{abstract}
Technological development causes infringement to e-book copyright especially e-novel by copying and distributing it without rights for example that is loaded on the website. In line with that, this study aims at explaining and analyzing the protection of adaptation rights for infringement in the form of e-novels by the website in the perspective of copyright law; and explaining and analyzing the legal consequences of the use of the e-novels by the website on the adaptation rights of the creator. This research uses normative juridical research with the approach to applying the laws of UUHC and the case approach in the form of the infringement of the e-novels on the website in www.corongbaca.com. The primary data taken from interview and the secondary data obtained from library studies. The data analyzed qualitatively and descriptively. The result of the study indicates that protection of the creator's adaptation rights from infringement of e-novels by the website in this case has not been realized because the creator who made the e-novel does not get benefit from the adaptation rights of the novel, namely royalties that are distributed based on an agreement with the website then regarding the legal consequences of using e-novels by websites on the author's adaptation rights, there are two consequences that have been carried out, namely: deletion of website content from www.corongbaca.com, and complaints to the Directorate General of Intellectual Property (DGIP), but there has been no follow up on the complaint. As for claims for compensation and criminal charges, the parties did not do so.
\end{abstract}

Keywords: adaptation rights; Copyright; copyright infringement; e-novels; website.

DOI: $10.32801 /$ lamlaj.v6i2.273 


\section{INTRODUCTION}

Era of the Industrial Revolution 4.0, human life has begun to enter digitalization since it cannot be separated from the flow of communication and information. The current of globalization is so fast that people are forced to know technology and information to be able to compete in global competition. People can access various kinds of digital information by using the internet network. By accessing internet, all needs can be done online and make things easier and more effective. The presence of the internet makes people create their intellectual ability so that they can be published to the wider community in a short time and easier, one of which is copyrighted works in the form of books. Books are human intellectual works that are protected by Copyright based on Article 40 section (1) letter (a) of Law Number 28 of 2014 concerning Copyright, abbreviated as UUHC, which states that books and all other written works are protected works.

Along with digitalization era that puts forward internet technology, books have turned into digital products. This is because most people read very differently today than they did a few years ago. While print may not be dead, people all over the world read digital screens on a regular basis and it's in electronic book or e-books. ${ }^{1}$ According to simple definition of Cambridge dictionary, an e-Book is "a book that is published in electronic form, for example on the Internet or on

\footnotetext{
Zakaria Issa Saleh and Ahmad Shaher Mashhur, "The Impact of E-Books on the Printed Books: E-Books Popularity, Growth and Future," in 2015 Fifth International Conference on E-Learning (Econf) (New York: Institute of Electrical and Electronics Engineers, 2015), 125-130, https://ieeexplore.ieee. org/stamp/stamp.jsp?tp=\&arnumber=7478221\&isnu mber $=7478193$.
}

a disk, and not printed on paper". This mainly expresses the notion of the electronic book, that uses the digital to support the same basic paper book characteristics, by emulate them. ${ }^{2}$ Because these books can be accessed through digital media, they have advantages in terms of use and storage that are more practical than printed books.

That e-book is a protected creation, because it is an adaptation form of a printed book. It is important to understand that a derivative work refers to the work as a whole, and not just to the modifications. preexisting material in the original work is part of the derivative work, but copyright in the derivative work only includes material contributed by the author of the derivative work, as distinguished from any preexisting material used in the work. ${ }^{3}$ Based on the Elucidation of Article 40 section (1) letter (n) UUHC, it is stated that what is meant by "adaptation" is to transform a creation into another form. This is also as stated in Article 40 section (2) UUHC which explains that the work as referred to in section (1) is protected as a separate work without reducing the copyright of the original work. The development of e-books in digital era can be easily modified by parties who do not have good faith, resulting in copyright infringement.

The form of e-book copyright infringement can be in the form of duplicating the

\footnotetext{
2 Yousef Daradkeh, Dren Selimi, and Luis Borges Gouveia, "E-BOOKS vs. P-BOOKS: WHO'S PROFITING?," European Scientific Journal, ESJ 8, no. 6 (2012): 178, https://eujournal.org/index.php/esj/ article/view/109.

3 J. (Jay) T. Westermeier, "Understanding the Importance of Derivative Works," Finnegan, last modified 2009, accessed August 25, 2021, https://www.finnegan.com/en/insights/articles/ understanding-the-importance-of-derivative-works. html.
} 
e-book, then the party which has no good intention sell it at a lower price than that the original e-book without the rights of the creator. For example about this duplication can be exemplified in Tere Liye's novels and Raditya Dika's novels. As it is known that Tere Liye and Raditya Dika are novel authors. The book that is meant to be duplicated here is a novel adapted in an electronic novel on the website. Novel adaptation rights as copyright is the exclusive right of the author in this case, Tere Liye and Raditya Dika to make derivative works in the form of electronic novels based on protected works, namely the printed version of the novel and when there are other parties who make derivative works without permission from the author will be considered as copyright infringement. The author in the context of the discussion of this paper will then be equated with the creator.

Is this novel is the same as the book. There is a quote that we often hear: "A novel can be called a book, but a book cannot necessarily be interpreted as a novel". ${ }^{4} \mathrm{~A}$ book is a collection of written works containing content (pictures and/or writing). A book can be called a novel if the content of the book contains a story that is divided into several chapters, then compiled into one. ${ }^{5}$ Thus the electronic novel in this case study can be categorized as an electronic book as well. However, for the similarity of the term, the author will only use

\footnotetext{
4 Eva D'zz, "Perbedaan Buku Dan Novel - Reading A Book Or Novel? (Penulis VS Pengarang)," GadoGado Land, last modified 2015, accessed August 30, 2021, http://www.evadollzz.com/2015/01/perbedaanbuku-dan-novel-reading-books-or-novels.html.

5 Herdina Primasanti, “Apa Perbedaan Buku Dan Novel? Apakah Novel Termasuk Buku?," Quora, accessed August 25, 2021, https://id.quora.com/Apaperbedaan-buku-dan-novel-Apakah-novel-termasukbuku.
}

the word electronic novel or e-novel.

Novels belonging to the authors ${ }^{6}$ as mentioned above are sold on unofficial sites such as http://ruangbacaan.com, Indonesia e-book,https://gerbangputra.blogspot. com,https://sarjanaberilmu.blogspot. com,https://alfan.id,http://ebookindolist. blogspot.com. On the other hand, Tere Liye himself explained how to download official e-books only through the Google Play Store application and the National Library's Puspas application for free. ${ }^{7}$

In line with e-book copyright, some previous research have been conducted. Labetubun stated that electronic books are intellectual property protected as the exclusive right of the creator regulated in UUHC. For those who violate the right, the copyright holder can sue them to the Commercial Court. ${ }^{8}$ Similar to this statement, Manuaba and Sukihana argued that electronic books (e-books) are a form of adaptation or transformation of printed books so that electronic books (e-books) must be protected. For people who want to convert a

\footnotetext{
${ }^{6}$ An author is someone whose written work has been published. In addition to producing published work, people who write are considered authors when they originate the ideas and content of their written work. For this reason, most authors are writers, but not all writers are considered to be authors, in MasterClass staff, "Writer vs. Author: What's the Difference?," Master Class, last modified 2021, accessed August 25, 2021, https://www.masterclass.com/articles/ writer-vs-author-whats-the-difference\#what-is-awriter.

7 Tia Agnes, "Viral Maraknya Kasus E-Book Ilegal Di Tengah Pandemi Corona," Detikhot, last modified 2020, accessed June 5, 2021, https://hot.detik.com/ book/d-4960792/viral-maraknya-kasus-e-bookilegal-di-tengah-pandemi-corona.

8 Muchtar Anshary Hamid Labetubun, “Aspek Hukum Hak Cipta Terhadap Buku Elektronik (E-Book) Sebagai Karya Kekayaan Intelektual," SASI 24, no. 2 (2018): 148, https://fhukum.unpatti.ac.id/jurnal/sasi/ article/view/128.
} 
printed book into an electronic book (e-book), they must obtain permission from the creator through a license agreement made by the parties and must meet the legal requirements of the agreement as stipulated in Article 1320 of the Civil Code. Article 1320 regulates the conditions for the validity of the agreement. In case of infringement in the duplication of electronic books without the permission of the creator, the case can be resolved through a court and without going through a court (UUHC article 95, section 1). ${ }^{9}$

Although this study points to e-books as the object of research, this research focuses on fiction e-books, namely e-novels which are then published on the website as done by https://www.corongbaca.com. The website provides twenty six categories of e-books ranging from fiction and non-fiction. The ebook is in the form of a PDF (Portable Document Format) and it is duplicated without permission from the creator and downloaded for free. This form sold at a price of Rp. 100.000, per category, or 3000 per e-books only one time download that have been arranged in a folder (fiction or non-fiction). This research also discusses a novel published by PT. Media ideas with the author Raditya Dika and PT. Gramedia Pustaka Utama with the creator is Tere Liye. Based on article 9 sections (2) and (3) of the UUHC, the unauthorized reproduction of e-books violates the economic rights of the creator then it sold for personal gain. In this case, economic rights, as an exclusive rights, granted to the creator Raditya Dika and Tere Liye and to the publisher and at the same

\footnotetext{
${ }^{9}$ Ida Ayu Lidya Nareswari and Ida Ayu Sukihana, "Perlindungan Hak Cipta Pada Buku Elektronik (E-Book) Di Indonesia," Kertha Semaya : Journal Ilmu Hukum 8, no. 10 (2020): 1589, https://ojs.unud. ac.id/index.php/kerthasemaya/article/view/62448.
}

time as a copyright holder, namely PT. Gagas Media and PT. Gramedia Pustaka Utama.

Based on the problems, some questions arise: how to protect adaptation rights for infringement in the form of e-novels by the website in the perspective of copyright law? What is the legal consequences of the use of the e-novels by the website on the adaptation rights of the creator? In line with the questions, the research objectives are 1) explaining and analyzing the protection of adaptation rights for infringement in the form of e-novels by the website in the perspective of copyright law; and 2) explaining and analyzing the legal consequences of the use of the e-novels by the website on the adaptation rights of the creator.

\section{METHOD}

This research is a normative juridical research, by finding the rule of law, legal principles, and legal doctrine, to answer the legal issues faced in accordance with the perspective of legal science. ${ }^{10}$ The research is the approach to applying the laws of UUHC and the case approach on the website www.corongbaca.com. The data used in this study was secondary from examined library materials. The technique of collecting data focused on document study or library research by reading, studying, reviewing, analyzing laws and regulations, documents, archives, and other literatures and to support this research, including primary legal material from UUHC, secondary from journal, and tertiary legal materials from dictionary. Legal principles or principles in accordance with the research objectives then about primary data by using interview by means of communication, through contacts or personal relationships between

\footnotetext{
${ }^{10}$ Peter Mahmud Marzuki, Penelitian Hukum, Revision E. (Jakarta: Kencana Prenada, 2015), 136
} 
data collection (interviewers) and data sources (respondents) conducted to creators and copyright holders. The data were analyzed qualitatively using a logical approach. This is classified and interpreted in written form so that the object of research can be clearly described. ${ }^{11}$ so that the research objectives will be answered.

\section{ANALYSIS AND DISCUSSION}

Protection of adaptation rights for infringements in the form of e-novel by Website in the perspective of copyright law

The case of e-books referred to in this study is e-novel in digital form from printed novel, generally consisting of a stack of bound paper containing text and images. This e-novel is available on the site with the context of the research, the term of 'e-novel' referred to fiction and non-fiction in the website www.corongbaca.com. The website provides 26 (twenty six) categories of e-books ranging from fiction and non-fiction. The non-fiction categories include science e-books such as philosophy, history, religion, politics, economics, humanities, international relations, Islamic philosophy, ideology books, biographies, anarchism, Indonesian, communication, psychology, and translation dictionaries. The fiction categories include novels, humor, short stories, mixtures, conspiracies, magazines, Islamic novels, illuminati, inspiration. The website www.corongbaca.com divides the list of names of each author alphabetically started from the letter A to $\mathrm{G}$, the letter $\mathrm{H}$ to $\mathrm{O}$ and the letter $\mathrm{P}$ to $\mathrm{Z}$. The e-books provided by the www.corongbaca.com used some authors such as Agatha Christie, Ahmad Fuadi, Ahmad Tohari, Ahmad Wahib, Al-Ghazali, Al-

\footnotetext{
${ }^{11}$ Suharsini Arikunto, Prosedur Penelitian Suatu
} Pendekatan Praktis (Jakarta: Rineka Cipta, 1993), 65 bert Camus, Andrea Hirata, Asma Nadia, Ayu Utami, Azizah Attaimimi, Bois, Boy Candra, Dee Lestari, Eka Kurniawan, Emha Ainun Nadjib, Frederick Engels, Habib El Shirazy, Haidar Bagir, Hamka, Harun Yahya, Hilman Hariwijaya, Ilana Tan, JK Rowiing, John Grisham, John Roosa, Joko Pinurbo, Jostein Gaarder, Karl Marx, Lenin, Murtadha Muthahari, Nurcholish Madjid, Supardi J Damono, Soe Hoek Gie and Tan Malaka. Moreover, the e-books contained on the www.corongbaca. com are also owned by several author in Indonesia and their works in the form of novels have been enjoyed by the public, including the object of the case in this study, the creator of Raditya Dika and Tere Liye.

As it is known that e-books can be opened with various kinds of software including Adobe Acrobat, Microsoft word and many more depending on the format you have. The enovel in this case study is in pdf format. PDF, which stands for Portable Document Format, is the most common format of e-books, used for document exchange with support for many platforms. In the future, it is also possible that as technology develops, new formats of e-books will emerge that will adapt to user needs. The e-book formats include:

a. AZW (Amazon World);

b. EPUB (Electronic Publication) or open digital book dari International Digital Publishing Forum (IDPF);

c. KF8 (Kindle Fire) a format that's basically the same principle as ePub organized in a Palm File Database (PDB) wrapper;

d. MOBI (MobiPocket)

e. PDB (Palm Database);

f. In addition to these formats, there are also PRC (Palm Resource), HTML (Hyper Text Markup Language), CHM (Compressed 
HTML), XHTML and XML formats. ${ }^{12}$

Based on the results of this research, the way to get an e-novel is by downloading one e-book for one category freely or you can pay Rp. 100,000 (one hundred thousand rupiah) to get 3000 (three thousand) e-books with downloading once for all categories of fiction or non-fiction arranged in a Portable Document Format folder. There is no difference of the e-novel cover between www.corongbaca.com e-book with the official market like Google Play Book. The only difference aspect can be seen when downloading one of the novel from Raditya Dika, Cinta Brontosaurus, which it is copied by scanning and changed in portable document format by www.corongbaca.com. In Google Play Book, this e-novel sold at a price of Rp. 21.000,-(twenty one thousand rupiah). Another case found in one of Tere Liye's works. The e-novel of Tere Liye sold at a price of Rp. 50,000, - (fifty thousand rupiah) up to Rp. 60,000, (sixty thousand rupiah) in Google Play Book, meanwhile www. corongbaca.com site sold it at a price of $\mathrm{Rp}$. 100.000,- (one hundred thousand rupiah) and get all available e-novel.

Things in the form of actions that are carried out by the www.corongbaca.com site as described above are categorized as infringement of adaptation rights. Infringement in the form of the right to adapt this case was carried out without rights and intentionally made an e-book novel by scanning physical e-book novel entitled Ubur-Ubur Lembur, Koala Kumal, Cinta Brontosaurus, Marmut

\footnotetext{
${ }^{12}$ Mohamad Aji and Dwi Widjanarko, "Pengembangan Media Pembelajaran Memahami Dan Memelihara Sistem Starter Tipe Konvensional Berbasis Buku Digital Electronic Publication (EPUB)," Jurnal Pendidikan Teknik Mesin 16, no. 1 (2016): 159, https://journal.unnes.ac.id/nju/index.php/JPTM/ article/view/9154.
}

Merah Jambu. This site is also scanning and distributing e-book novels from PT. Gramedia Pustaka Utama as publisher and Tere Liye as the author to some books entitled Comet, About Love, Bulan, Matahari, Hujan. The e-book novel was then sold on the website www.corongbaca.com at a lower price.

This adaptation right is regulated as a protected work in Article 40 UUHC paragraph (1) letter (n) stating that the protected work is in the form of translation, interpretation, adaptation, anthology, database, adaptation, arrangement, modification and other works resulting from the transformation. Elucidation This article provides an explanation of what is meant by "adaptation" is to transform a creation into another form. The transformation in this case is from the initial form of the novel by the creators of both Raditya Dika and Tere Liye in the form of a hard copy to a soft copy in the form of an e-book. Protection of e-novel adaptation rights is the protection of derivative works based on Article 59 paragraph (1) letter (g). Derivative works are creations as a result of further processing of the original works, further works also receive the same legal protection as the original works. The validity period of copyright for derivative works is 50 (fifty) years from the first announcement.

The existence of this adaptation right in UUHC is generally included in the economic rights regulated in Article 8 which states that economic rights are the exclusive rights of the creator or copyright holder to obtain economic benefits from the creation. The economic benefit in Article 9 paragraph (1) letter (d) is that the creator or copyright holder has the economic right to adapt the work. These economic rights are rights related to the commercial use of a work and related to the protec- 
tion of the economic needs of the creator, for example the right to receive royalty payments for the use of protected copyrighted works. The higher the quality of a work, the higher the potential commercial value. Article 9 paragraph (2) and (3) of the UUHC explain that everyone who has economic rights must obtain the author's permission, and anyone without the permission of the author or copyright holder, is prohibited from commercially copying the work.

Based on the results of interviews, both the creator and the two publishers as creators' copyright holders have made efforts to protect the adaptation rights to novels in the form of preventive measures to provide copyright protection for creators by notifying through social media accounts regarding pages to buy novels and then also registering for the copyright. Another effort is repressive in the form of complaints to the ministry related to this case. For example, PT. Gagas Media, as publisher and copyright holder of Radiyta Dika's novels, provides facilities for the public to access and read published e-books on its official website on www.gagasmedia.net, buy it on Google Play Book, and read for free at i-Pusnas, a national library based on digital. Furthermore, PT. Gagas Media also has a special division team concerns with book piracy. The task is to record, warn or reprimand copyright violators and cooperate with the marketplace to accelerate strict action against the sale of pirated books or e-books on their platform.

Similar to this, the results of interviews with other publishers, namely PT. Gramedia Pustaka Utama as the publisher who is also a copyright holder of Tere Liye's novel takes preventive steps by protecting using a watermark on every e-book issue, it cannot be screened using a smartphone and socializing to the public via social media Instagram by giving warnings to anyone who have no good intention to commit copyright infringement. The method used by PT. Gramedia Pustaka Utama warns that anyone cannot download and trade the e-book on blog sites, websites or social media without permission. Since it involves respecting the rights and efforts of the author and all parties involved in it, there will be sanctions imprisonment for a maximum of 10 (ten) years in accordance with the provisions in UUHC. ${ }^{13}$

Meanwhile, Tere Liye himself has played an active role in protecting his creations by writing information on his personal Facebook page. Tere Liye explained that his books are sold on the marketplace or online trading and convince that the books or e-books are pirated. If people want to read his works, they can borrow books from friends, the library or read them on i-pusnas using the online application of the Indonesian Library. Tere Liye has also reported infringement of adaptation rights that harm the economic rights of his novel to the Directorate General of Intellectual Property (DGIP), but there has been no follow-up on the protection of his creations.

The background section above has also mentioned about other unofficial sites outside of the website in this discussion such as http:// ruangbacaan.com, especially on its Facebook page that still provides various free e-books, the site owner said that all ebooks posted on the site it is used as a personal ebook collection/library then other addresses such as Indonesia e-books, the site does provide free e-books but must verify and select certain

\footnotetext{
13 "Instagram Resmi Buku Gramedia Pustaka Utama, (@BukuGPU)," Instagram, accessed June 5, 2020, https://www.instagram.com/p/B_12skNJDcc/?utm_ source=ig_web_copy_link.
} 
applications, then the site https://gerbangputra.blogspot.com, https://sarjanaberilmu. blogspot.com, http.alfan.id and http://ebookindolist.bl, all of these sites provide the author's novels to be downloaded for free by readers from google drive who have they provide. The existence of these unofficial sites can be used as a comparison that there are many similar infringement of this adaptation right.

In line with the report made by creators in the discussion of this research case, Directorate General of Intellectual Property (DGIP), explained that to obtain legal protection, the creator, in this case it is novelist Raditya Dika and Tere Liye must register his copyrighted work in the form of a novel with the Directorate General of Intellectual Property (DGIP) to obtain a registration certificate that provides permanent legal protection. It aims to strengthen legal protection of the rights of creators and strengthen evidence in case of copyright infringement in the future. The author or copy must play an active role in infringement that harms their economic rights by being competent and caring about the rights of the author or copyright holder. Copyright protection can be realized in both legal protection with investigators and the participative author or copyright holder in maintaining the rights they have. Consequently, public must be aware of not using the work without the rights of the creator or copyright holder. Thus, according to the researcher, UUHC has regulated the creation, including in the case that UUHC adheres to a negative declarative system. UUHC has given a sense of legal protection, however, if law enforcement officials have not been able to provide legal protection, then legal protection for creators or copyright holders didn't run well. To get protection from law enforcement officers, PT. Gagas Media and PT. Gramedia Pustaka Utama must file a complaint with the Directorate General of Intellectual Property (DGIP) in order to obtain legal protection for duplication by www.corongbaca.com and in order to receive and recover their rights granted by UUHC. As for this complaint, no reports have been submitted to the Directorate General of Intellectual Property (DGIP).

\section{The legal consequence of the use of the e- novels by the website on the adaptation rights of the creator.}

Legal consequences are all consequences that occur from all legal actions carried out by legal subjects against legal objects or other consequences caused by certain events which have been determined by the law concerned or considered as legal consequences. ${ }^{14}$ The actions of www.corongbaca.com which have infringed copyright in the form of adaptation rights as described in the previous sub by duplicating and distributing e-book novels published by PT. Gagas Media as the copyright holder of the creator's work, in this case Raditya Dika and PT. Gramedia Pustaka Utama as the copyright holder of the creator Tere Liye can of course have legal consequences. There is a legal consequence because a creation, namely a novel belonging to the author, in this case has exclusive rights based on Article 4 UUHC, one of which is economic rights. Exclusive rights in the form of economic rights can be in the form of royalties paid by www.corongbaca.com based on the distribution of calculations based on the agreement in the agreement. Royalties stated in Article 1 number 21 UUHC are rewards for the use

\footnotetext{
${ }^{14}$ Muhammad Sadi Is, Pengantar Ilmu Hukum (Jakarta: Kencana, 2015), 90
} 
of economic rights of a work or product of related rights received by the creator or owner of the related rights.

Based on the results of the research, the amount of royalties paid by the publisher to the author is based on the selling price of the books sold and the royalties are progressive with the provision that the sales figure is up to 10,000 (ten thousand) copies of the royalties received by $10 \%$ (ten percent), sales figures from 10,001 (ten thousand one) to 20,000 (twenty thousand) copies will receive an additional royalty bonus of $1 \%$ (one percent) and sales figures above 20,001 (twenty thousand one) copies will receive an additional royalty bonus of $2 \%$ (two) percent).

As the infringement of adaptation rights committed by www.corongbaca.com which has duplicated and disseminated the work without rights from the creator, namely the author of the novel and the copyright holder, namely the publisher of the novel in this discussion and then also does not provide royalties to the rights owners, the legal consequences that can occur are as follows: First, the removal of the content of the website www.corongbaca. com. And at this moment the website accent can't be opened anymore. This consequence regulated in article 56 paragraph (1) and (2) UUHC and in the provisions of article $13 \mathrm{sec}-$ tion (1) of the Joint Regulation of the Minister of Law and Human Rights of the Republic of Indonesia and the Minister of Communication and Information Technology Number 14 of 2015 and Number 26 of 2015 regarding the implementation of closing content and/ or user access rights violations of copyright and/or related rights in electronic systems. It explains that the minister of telecommunications and informatics can close content, and/ or access users who violate copyright and/or related rights in electronic systems and make electronic system services inaccessible and further provisions regarding the implementation of content closures and/or access rights of users who violate copyrights and/or related rights in electronic systems or make electronic system services as referred to in section 1 shall be stipulated by a joint regulation of the minister of communication and informatics.

Second, parties who are harmed by their economic rights due to infringing the adaptation rights, namely both the creator and or the copyright holder can take dispute resolution efforts based on Article 95 of the UUHC and in a lawsuit if they use the means of a commercial court, then the right to ask for civil compensation in the form of calculating material losses, royalty payments on adaptation rights belonging to the creator and or from the copyright holder. This is in line with article 96 sections (1) and (2) UUHC number 28 of 2014 explains that creators, copyright holders and/or related rights holders or their heirs who have suffered economic rights losses are entitled to compensation.

The next paragraph in the same article, namely Article 96 UUHC explains that the claim for compensation as referred to in paragraph (1) can be in the form of a request to surrender all or part of the income obtained from holding lectures, scientific meetings, performances or exhibitions of works that are the result of copyright infringement or related rights products. In line with this, Saidin stated that in order to file a claim for compensation, the element of an act against the right must first be fulfilled by presenting a person who made a mistake and caused another person to suffer losses, ${ }^{15}$ in this case it was carried out by www.corongbaca.com. Compensation will

\footnotetext{
${ }^{15}$ Ibid
} 
be given and listed in advance in the court's decision regarding the copyright crime case. The reality in this case is that this case was not brought to the commercial court so that the implementation of this article cannot be carried out.

Third, www.corongbaca.com Parties who infringe copyright in the form of adaptation rights may be subject to criminal sanctions based on complaints from the creator and or copyright holder in accordance with Article 113 paragraph (2) of the UUHC states that Anyone who without rights and/or without permission An Author or Copyright holder who infringes the economic rights of the $\mathrm{Au}$ thor for Commercial Use shall be sentenced to a maximum imprisonment of 3 (three) years and/or a maximum fine of Rp. 500,000,000 (five hundred million rupiah). Based on the results of the research, because there has been no complaint from the creator and or copyright holder, this case cannot be followed up properly in accordance with UUHC. Copyright holders, including PT. Gagas Media and PT. Gramedia Pustaka Utama is aware of copyright infringement that occurs on websites, chat applications, and marketplaces, but it only collects data regarding the infringement of adaptation rights that occurred.

\section{CONCLUSION}

The conclusion of this research is that the protection of the author's adaptation rights from e-novel infringement by the ww.corongbaca.com site which reproduces and distributes the author's e-novel without permission and is in conflict with the author's rights has not been realized because the fulfillment of the author's exclusive rights is automatically in the form of economic rights, in the form of royalty payments to creators are not made by the website. Royalty payments can be made if there is a transfer of adaptation rights from the creator, in this case both Raditya Dika and Tere Liye. Then about the legal consequences of using e-novels by the website on the creator's adaptation rights are two things, namely the deletion of content from the www.corongbaca.com site then the Creator has also submitted a complaint to the Directorate General of Intellectual Property (DGIP) by making a complaint through the website https://e-pengaduan.dgip .go.id/, but violators are not penalized because there is no follow-up to the complaint.

Suggestions that can be given are creators and copyright holders should always take two steps of protection, both preventive, by recording copyrights, and repressive, by protecting their copyrighted works. The Directorate General of Intellectual Property (DGIP) should always cooperate with other relevant ministries related to copyright enforcement and socialize it to the creators and copyright holders.

\section{BIBLIOGRAPHY}

\section{Books}

Arikunto, Suharsini. Prosedur Penelitian

Suatu Pendekatan Praktis. Jakarta: Rineka Cipta, 1993.

Is, Muhammad Sadi. Pengantar Ilmu Hukum. Jakarta: Kencana, 2015.

Marzuki, Peter Mahmud. Penelitian Hukum. Revision E. Jakarta: Kencana Prenada, 2015.

\section{Journal}

Aji, Mohamad, and Dwi Widjanarko. "Pengembangan Media Pembelajaran Memahami Dan Memelihara Sistem Starter Tipe Konvensional Berbasis Buku Digital Electronic Publication (EPUB)." 
Jurnal Pendidikan Teknik Mesin 16, no. 1 (2016): 159. https://journal.unnes.ac.id/ nju/index.php/JPTM/article/view/9154.

Daradkeh, Yousef, Dren Selimi, and Luis Borges Gouveia. "E-BOOKS vs. P-BOOKS: WHO'S PROFITING?" European Scientific Journal, ESJ 8, no. 6 (2012): 178. https://eujournal.org/index. php/esj/article/view/109.

Labetubun, Muchtar Anshary Hamid. "Aspek Hukum Hak Cipta Terhadap Buku Elektronik (E-Book) Sebagai Karya Kekayaan Intelektual." SASI 24, no. 2 (2018): 148. https://fhukum.unpatti.ac.id/ jurnal/sasi/article/view/128.

Nareswari, Ida Ayu Lidya, and Ida Ayu Sukihana. "Perlindungan Hak Cipta Pada Buku Elektronik (E-Book) Di Indonesia." Kertha Semaya: Journal Ilmu Hukum 8, no. 10 (2020): 1589. https://ojs.unud. ac.id/index.php/kerthasemaya/article/ view/62448.

\section{Internet}

Agnes, Tia. "Viral Maraknya Kasus E-Book Ilegal Di Tengah Pandemi Corona." Detikhot. Last modified 2020. Accessed June 5, 2021. https://hot.detik.com/ book/d-4960792/viral-maraknya-kasus-ebook-ilegal-di-tengah-pandemi-corona.

D’zz, Eva. 'Perbedaan Buku Dan Novel Reading A Book Or Novel? (Penulis VS Pengarang)." Gado-Gado Land. Last modified 2015. Accessed August 30, 2021. http://www.evadollzz.com/2015/01/ perbedaan-buku-dan-novel-readingbooks-or-novels.html.

MasterClass staff. "Writer vs. Author: What's the Difference?" Master Class. Last modified 2021. Accessed August 25, 2021. https://www.masterclass.com/ articles/writer-vs-author-whats-the- difference\#what-is-a-writer.

Primasanti, Herdina. “Apa Perbedaan Buku Dan Novel? Apakah Novel Termasuk Buku?" Quora. Accessed August 25, 2021. https://id.quora.com/Apa-perbedaanbuku-dan-novel-Apakah-novel-termasukbuku.

Westermeier, J. (Jay) T. "Understanding the Importance of Derivative Works." Finnegan. Last modified 2009. Accessed August 25, 2021. https://www.finnegan. com/en/insights/articles/understandingthe-importance-of-derivative-works.html.

"Instagram Resmi Buku Gramedia Pustaka Utama, (@BukuGPU).” Instagram. Accessed June 5, 2020. https://www. instagram.com/p/B_12skNJDcc/?utm_ source=ig_web_copy_link.

\section{Conference}

Saleh, Zakaria Issa, and Ahmad Shaher Mashhur. "The Impact of E-Books on the Printed Books: E-Books Popularity, Growth and Future." In 2015 Fifth International Conference on E-Learning (Econf), 125-130. New York: Institute of Electrical and Electronics Engineers, 2015. https://ieeexplore.ieee.org/stamp/ stamp.jsp?tp=\&arnumber $=7478221 \&$ isnu mber $=7478193$. 